\title{
The effects of green tea extract and vitamin $E$ on the growth performance and immune response in broiler chicks
}

\author{
Ebrahim Rowghani $^{1 *}$, Seyed Ali Tabeidian ${ }^{2}$ and Ebrahim Abolfathi ${ }^{1}$ \\ ${ }^{1}$ Department of Animal Sciences, College of Agriculture, Darab Branch, Islamic Azad University, Darab, Iran; \\ ${ }^{2}$ Department of Animal Sciences, College of Agriculture, Khorasgan Branch, Islamic Azad University, Isfahan, Iran
}

\begin{abstract}
Article history
Received: 9 Aug, 2016

Revised: 28 Aug, 2016

Accepted: 30 Aug, 2016

Abstract

The effects of green tea extract (GTE) on growth performance and immune response were investigated. In a completely randomized design, three hundred sixty Ross 308 strain broiler chicks was assigned to 6 treatments, 4 replicates and 15 chicks in each experimental unit. The experimental treatments were added to the basal (starter, grower and finisher) diets as follows: (1) basal diet,without additives and received only basal diets; (2) basal diets plus $20 \mathrm{IU} / \mathrm{kg}$ Vit. E; (3) basal diets plus $3 \mathrm{ml} / 1$ drinking water GTE with $20 \mathrm{IU} / \mathrm{kg}$ Vit. E; (4) basal diets plus 3ml/1 drinking GTE; (5) basal diets plus $5 \mathrm{ml} / 1$ drinking water GTE and (6) basal diets plus $5 \mathrm{ml} / 1$ drinking water GTE with $20 \mathrm{IU} / \mathrm{kg}$ Vit. E. The chicks were fed diet supplied with $3 \mathrm{ml} / \mathrm{l} \mathrm{GTE}$ (treatment 4) significantly $(\mathrm{P}<0.05)$ had higher final body weight, daily weight gain, daily feed intake and better feed conversion ratio. Treatment $6(5 \mathrm{ml} / 1$ drinking water GTE with $20 \mathrm{IU} / \mathrm{kg}$ Vit. E), non-significantly had higher blood Newcastle antibody titer compared with other treatments. Treatment 5 and 6 had significantly $(\mathrm{P}<0.05)$ higher and treatment 4 had a lower Influenza antibody titer, respectively. Non-significantly higher antibody titer against SRBS was observed for treatment 2 (20 IU/kg Vat. E). Adding GTE was not able to improve total antioxidant capacity (TAC) and treatment 2 $(20 \mathrm{IU} / \mathrm{kg}$ Vit. E) had significantly $(\mathrm{P}<0.05)$ higher serum TAC concentration compared with other treatments. The results indicated that the addition of $3 \mathrm{ml} / \mathrm{l}$ drinking water GTE had the most positive effects on growth performance traits and application of $5 \mathrm{ml} / \mathrm{l} \mathrm{GTE}$ alone or in combination with $20 \mathrm{IU} / \mathrm{kg}$ diet Vit. E may have a complementary effect on the serum antibody titers against Influenza and had the potential in replacing antibiotics in broiler chicks.

Keywords: Green tea extract; performance; immune response; vitamin E; broiler chicks
\end{abstract}

\footnotetext{
To cite this article: Rowghani E, SA Tabeidian and E Abolfathi, 2016. The effects of green tea extract and vitamin e on the growth performance and immune response in broiler chicks. Res. Opin. Anim. Vet. Sci., 6(7): 200-205.
}

\section{Introduction}

Farm animals in intensive farming operations are frequently subjected to different stresses. Nutrition plays a significant role in the modulation and the function of the immune response of chicks (Klasing, 1998; Kidd, 2004). Any deficiencies of natural protective substances or severe exposure to stimulators of reactive oxygen metabolites production (Miller et al., 1993) could increase damage of important biological

*Corresponding author: Rowghani E. Department of Animal Sciences, College of Agriculture, Darab Branch, Islamic Azad University, Darab, Iran; Email: erowghani@ yahoo.com 
macromolecules e.g. lipids, proteins and DNA, interfering their normal function and consequently leading to reduced performance (Valko et al., 2007). Poultry possesses limited natural resistance against pathogenic organisms. Therefore, the poultry industry has relied on the use of antibiotics to improve health and productivity. Owing to the outbreaks of resistant bacteria and residues of antibiotics in animal products, using antibiotics is regulated by governments in the world. In addition, the use of antibiotics in animal production is under severe public scrutiny because livestock production activities have been linked to the development of antibiotic-resistant bacteria within the human population (Radcliff, 2000; Phillips et al., 2004). The poultry industry is compelled to find alternatives to the use of antibiotics in order to maintain and enhance markets for safe poultry products. There are several kinds of alternatives developed and used recently, among which readily noticeable natural substances for customers and medicinal plants with excellent physiological activity are drawing attention of the researchers (Hernandez et al., 2001). The important medicinal herbs include are green tea, artemisia, garlic and others (Yang et al., 2003; Kwon et al., 2005). Beneficial activity of plant extracts has contributed to the content of different secondary metabolites such as polyphenols, carotenoids, triterpens and essential oils. These polyphenols capture free radicals, chelate metal ions and inhibit lipoxygenase, so they can be used as natural preservatives inhibiting the onset of peroxidation of oils (Ramadan et al., 2003; Papuc et al., $2007 \& 2008$ ). This property could be attributed to the essential oil content that have antimicrobial, antifungal and antioxidant activities, thus could improve the birds dietary nutrient utilization (Williams and Losa, 2001). Inclusion of green tea (Camellia sinensis) powder has shown beneficial effects on egg quality traits (Biswasa et al., 2000) and lowered cholesterol and triglyceride content of eggs (Biswas and Wakita, 2001; Koo and Noh, 2007). The green tea extract increased body weight, feed efficiency, carcass weight and dressing percentage (Guray et al., 2011). The broilers in green tea extract supplemented groups consumed more feed than the control birds throughout the entire experimental period. Green tea inclusion in broiler diets had positive effects on growth performance and lean meat production of broilers (Kaneko et al., 2001).

Vitamin $\mathrm{E}$ is the most active natural antioxidant, which has been used in animal feed to enhance performance, strengthens immunological status and possibly to increase the vitamin content of food of animal source and thus increase the vitamin $\mathrm{E}$ intake of consumers (McDowell, 1989; Flachowsky, 2000). Vitamin E like other nutritional elements, affects the development and maintenance of immunocompetence through multiple functions by affecting directly on immune cells or by indirectly altering metabolic and endocrine parameters, thus influencing immune function (Gershwin et al., 1985). As an antioxidant, vitamin E reduces free radical-induced pathology during both normal metabolic states and inflammation. In addition, vitamin $\mathrm{E}$ modulates the metabolism of arachidonic acid through cyclooxygenase and lipoxygenase pathways (Blumberg, 1994), which in turn leading to the synthesis of prostaglandins and leukotrienes respectively. It has been reported that the immunity of chickens increased against Newcastle (Boren and Bond, 1996), Escherichia coli and Brucella abortus (Tengerdy and Nockels, 1975).

The objectives of the current study were to determine the effects of green tea extract and vitamin $\mathrm{E}$ on productive performance and immune response of broiler chicks.

\section{Materials and Methods}

A total of three hundred sixty one day-old broiler chicks (Ross 308) were obtained from local market and divided into 24 groups (15 chicks per cage with similar body weight). An experiment was conducted as a completely randomized design and six dietary treatments were utilized. The composition of the starter, grower and finisher diets is presented in Table 1. The diets were formulated according to the Ross company recommendation to meet nutrient requirements of the chicks and were fed for days 0-42. Experimental treatments were as follows: basal diet, without additives and received only basal diets; basal diets plus $20 \mathrm{IU} / \mathrm{kg}$ Vitamin E, basal diets plus $3 \mathrm{ml} / 1$ drinking water GTE with $20 \mathrm{IU} / \mathrm{kg}$ Vitamin E, basal diets plus $3 \mathrm{ml} / 1$ drinking water GTE, basal diets plus $5 \mathrm{ml} / 1$ drinking water GTE and basal diets plus $5 \mathrm{ml} / \mathrm{l}$ drinking water GTE with $20 \mathrm{IU} / \mathrm{kg}$ Vitamin E. Strict sanitation practices were maintained in the house before and during the course of study. The chicks were housed in a temperature controlled room with continuous lighting and feed and water were provided ad libitum throughout the experiment. Mortality was recorded daily. Chickens were weighed every 2 weeks and feed consumption calculated for every 2 weeks. Body weight (BW, g) and feed intake (hen-day; g/h/d) by replicate were determined for every experimental period for all birds. Average daily gain (ADG, g/day) feed conversion ratio (FCR g/g) was then calculated. FCR was corrected for mortality. Birds were vaccinated against Gamboro, Newcastle (Lasota), Influenza and Bronchitis according to laboratory recommendations. Fresh green tea leaves were provided from a local factory. In order to destroy the activity of polyphenol oxidase, the fresh leaves were put in boiling water for 3 $\min$. Then the leaves were dried indoor and grounded. Four grams of grounded sample were autoclaved (80 - 
Table 1: Composition (\%) of basal diets fed to broiler chickens

\begin{tabular}{lccc}
\hline Ingredients & $\begin{array}{c}\text { Starter } \\
(1-14 \mathrm{~d})\end{array}$ & $\begin{array}{c}\text { Grower } \\
(15-28)\end{array}$ & $\begin{array}{c}\text { Finisher } \\
(29-49)\end{array}$ \\
\hline Corn & 56.06 & 58.14 & 62.01 \\
Soybean meal & 37.98 & 35.93 & 31.89 \\
Soya oil & 1.55 & 2.12 & 2.46 \\
Monocalcium phosphate $*$ & 1.35 & 1.15 & 1.10 \\
Calcium carbonate & 1.75 & 1.45 & 1.39 \\
Salt & 0.35 & 0.35 & 0.35 \\
DL -Methionine & 0.31 & 0.28 & 0.21 \\
L-Lysine HCl & 0.19 & 0.12 & 0.13 \\
Vitamin premix** & 0.25 & 0.25 & 0.25 \\
Mineral premix*** & 0.25 & 0.25 & 0.25 \\
Nutrient content & & & \\
$\quad$ ME (Kcal/Kg) & 2879 & 2950 & 3017 \\
Crude protein & 22.00 & 21.20 & 19.73 \\
Calcium & 0.99 & 0.84 & 0.80 \\
Available phosphorus & 0.47 & 0.42 & 0.40 \\
Methionine+ cysteine & 1.01 & 0.97 & 0.86 \\
Lysine & 1.40 & 1.29 & 1.19 \\
\hline
\end{tabular}

*Contained $\mathrm{Ca} 15 \%$ and phosphorous 23\% ** Provided per 2.5 kilogram :Vitamin A,9000000 IU; Vitamin D3,2000000 IU; Vitamin E, Vitamin E, 18000mg; Vitamin K3, 2000mg; Thiamine, $1800 \mathrm{mg}$; Riboflavin, 6600mg;Pantothenic acid, 10 g; Niacin, 30g; Pyridoxine, 3000mg;Cobalamin,15mg;Biotin, $100 \mathrm{mg}$; Folic acid,1000mg; Choline chloride 500mg; Antioxidant, $100 \mathrm{~g}$. *** Provided per $2.5 \mathrm{~kg}$ : Manganese, 100g; Zinc, 100g; Iron, 50g; Copper, 100g; I,1000mg; Selenium, $200 \mathrm{mg}$.

$120^{\circ} \mathrm{C}$ ) for $20 \mathrm{~min}$ with $40 \mathrm{ml}$ distilled water in order to obtain green tea extract. Humoral immunity was measured as antibody response to the injection of 1 $\mathrm{ml}$ of $10 \%$ solution of washed sheep red blood cells (SRBC) on day 25 (wing vein of 2 birds from each replicate) followed by agglutination assay on day 5 after the injection. Blood samples were taken from wing vein on day 30 for serum antibody titer analysis. The hemagglutination (HI) assay was performed as described by Singh et al. (2006) for SRBC, Newcastle and Influenza. The antibody titer was expressed as the $\log 2$ of the reciprocal of the highest titer with 50\% agglutination (Brugh, 1978; Nelson et al., 1995). At the end of the experiment (42 d), 2 birds from each replicate were bled by wing vein and plasma was used for total antioxidant capacity (TAC) according to the method described by Akhlaghi et al. (2014).

Analysis of variance was performed on the data using the General Linear Method of SAS software (1996). Means were compared using Duncan's multiple range test. Level of significance used in all results was 0.05 .

\section{Results}

The main effects of treatments on performance, antibody titers and TAC of broiler chicks are presented in Table 2. Chicks body weight significantly $(\mathrm{P}<0.05)$ differed between the experimental treatments during the whole experiment and treatment 4 (3ml/l GTE) had higher body weight with no significant difference between treatments 4 and 2. Daily gain was significantly $(\mathrm{P}<0.05)$ higher in treatment 4 with no significant difference with treatments 5 and 6 . Treatment 4 had significantly $(\mathrm{P}<0.05)$ higher daily feed intake though there was no significant difference between treatment 4,5 and 6 . Feed conversion ratio was affected $(\mathrm{P}<0.05)$ by treatments and was lowest (better) in treatment 4 with significant difference between treatment 3 and 4. Antibody titer $(\log 2)$ against Newcastle did not differ between treatments, though tended to be higher in treatment 6 . Antibody titer against influenza was influenced $(\mathrm{P}<0.05)$ by dietary treatments and treatments 5 and 6 had the highest value compared to the other treatments. The antibody titer against SRBC was not affected by dietary treatments, but treatment 2 tended to be higher compared with other treatments. TAC level was different $(\mathrm{P}<0.05)$ between treatments and treatment 2 was significantly higher than other treatments except treatment 1 .

Table 2: The main effects of treatments on performance, antibody titers and TAC of broiler chicks at day 42

\begin{tabular}{lccccccc}
\hline Parameters & \multicolumn{7}{c}{ Treatments* } \\
\cline { 2 - 7 } & 1 & 2 & 3 & 4 & 5 & 6 & SD** $^{*}$ \\
\hline Final body weight $(\mathrm{kg})$ & $2.99^{\mathrm{b}}$ & $3.05^{\mathrm{a}}$ & $2.94^{\mathrm{b}}$ & $3.37^{\mathrm{a}}$ & $2.91^{\mathrm{b}}$ & $2.90^{\mathrm{b}}$ & 0.13 \\
Daily gain (g/day) & $56.10^{\mathrm{b}}$ & $62.70^{\mathrm{b}}$ & $59.00^{\mathrm{b}}$ & $79.20^{\mathrm{a}}$ & $68.70^{\mathrm{ab}}$ & $64.20^{\mathrm{ab}}$ & 6.20 \\
Daily feed intake( g/day) & $118.10^{\mathrm{ab}}$ & $128.50^{\mathrm{b}}$ & $133.70^{\mathrm{ab}}$ & $150.40^{\mathrm{a}}$ & $131.90^{\mathrm{ab}}$ & $131.30^{\mathrm{ab}}$ & 7.93 \\
Feed convertion ration (g/g) & $2.22^{\mathrm{ab}}$ & $2.09^{\mathrm{ab}}$ & $2.31^{\mathrm{a}}$ & $1.90^{\mathrm{b}}$ & $1.94^{\mathrm{b}}$ & $2.05^{\mathrm{ab}}$ & 0.12 \\
Newcastle & $4.12^{\mathrm{b}}$ & $4.12^{\mathrm{b}}$ & 4.00 & $4.12^{\mathrm{a}}$ & 3.87 & 4.62 & 0.32 \\
Influenza & $4.25^{\mathrm{b}}$ & $3.75^{\mathrm{b}}$ & $3.75^{\mathrm{b}}$ & $3.50^{\mathrm{b}}$ & $5.37^{\mathrm{a}}$ & $5.25^{\mathrm{a}}$ & 0.28 \\
SRBC & $8.87^{\mathrm{ab}}$ & $9.12^{\mathrm{a}}$ & 8.50 & $8.62^{\mathrm{a}}$ & $8.75^{\mathrm{b}}$ & 8.88 & 0.31 \\
TAC $(\mu \mathrm{mol} / \mathrm{ml})$ & $0.52^{\mathrm{ab}}$ & $0.67^{\mathrm{a}}$ & $0.51^{\mathrm{b}}$ & $0.45^{\mathrm{b}}$ & $0.41^{\mathrm{b}}$ & $0.39^{\mathrm{b}}$ & 0.058 \\
\hline
\end{tabular}

*1): basal diet, without additives and received only basal diets; 2): basal diets plus $20 \mathrm{IU} / \mathrm{Kg} \mathrm{Vit.} \mathrm{E} \mathrm{3):} \mathrm{basal} \mathrm{diets} \mathrm{plus} 3 \mathrm{ml} / \mathrm{L}$ drinking water GTE with $20 \mathrm{IU} / \mathrm{Kg}$ Vit. E; 4): basal diets plus $3 \mathrm{ml} / \mathrm{L}$ drinking water GTE; 5): basal diets plus $5 \mathrm{ml} / \mathrm{L}$ drinking water GTE and 6) : basal diets plus $5 \mathrm{ml} / \mathrm{L}$ drinking water GTE with a ,b: values in the same row that share different superscript (s) are statistically different $(\mathrm{P}<0.05) * * \mathrm{SD}=$ standard deviation. 


\section{Discussion}

Supplementing diets with $3 \mathrm{ml} / \mathrm{l} \mathrm{GTE}$ in drinking water (treatment 4) was more effective on body weight than other treatments, though there was no significant difference between treatment 4 and treatments 5 and 6 . The increasing GTE from 3 to $5 \mathrm{ml} / \mathrm{l}$ to diets, decreased body weight $(3.37$ vs $2.91 \mathrm{~kg})$. These results were similar to findings of Kaneko et al. (2001) who reported that 1.0, 2.5 and $5.0 \%$ of green tea in broiler diets linearly reduced body weight gain of the chicks. Uuganbayar (2004) reported that 1.0 to $1.5 \%$ green tea supplement in broiler diet had reduced effect on body weight gain of chicks. Vitamin $\mathrm{E}$ alone or combination with $3 \mathrm{ml} / 1$ GTE was not able to increase body weight gain compared with $3 \mathrm{ml} / \mathrm{l}$ GTE. High level of tannin in green tea decreases the activities of several enzymes important to the digestion of carbohydrates, protein, lipids and nucleic acid. Soaking and extracting green tea were able to ameliorate the negative effects of tannin on performance of chicks (Biswas et al., 2001). It has been reported that the addition of 0.5 and $1.5 \%$ green tea to the diet of broiler chicks decreased the daily weight gain (Sarker et al., 2010) which is not in agreement with the result of the present experiment for daily weight gain as found in treatment $4(3 \mathrm{ml} / \mathrm{L} \mathrm{GTE})$. Kaneko et al. (2001) reported that 0.5 to 1.0 and 1.0 to $5.0 \%$ green tea supplementation in broiler diets reduced daily feed intake which is not in agreement with the findings of our results. Also, Kojima and Yoshida (2008) reported no significant changes in feed intake when layer diet was supplied by $1 \%$ green tea powder, which is in contrast to our results. Panja (2005) reported decreased feed intake when layer diet was supplied with green tea and a non-significant effect on feed consumption and feed conversion ratio when the diet was supplied with green tea and vitamin E. Guray et al. (2011) reported increased body weight, feed conversion ratio and carcass weight of broiler chicks when the diet was supplied with 1 to $4 \%$ alcoholic GTE. Compared to other treatments, chicks received $3 \mathrm{ml} / \mathrm{l} \mathrm{GTE}$ in the diet had the lowest feed conversion ratio. This is not in agreement with results of Uuganbayar et al. (2005) who reported no significant differences in feed conversion ratio among layers fed diets containing 1, 1.5 and $2.0 \%$ green tea powder and the control group. Sarker et al. (2010) reported no improvement in feed conversion ratio in broilers fed 1 and $2 \%$ green tea powder which is not in agreement with our findings.

Antibody titer with supplementation of $20 \mathrm{IU}$ Vitamin E and 5ml/l GTE was numerically higher than other treatments which showed vitamin $\mathrm{E}$ and higher level of GTE ( 3 vs $5 \mathrm{ml} / \mathrm{l}$ ) could play a complementary role on antibody response against Newcastle, in which higher level of GTE may enhance the effects of vitamin E. The same positive and significant $(\mathrm{P}<0.05)$ pattern was found in antibody response against influenza in chicks fed diet containing 5ml/1 GTE or 5ml/1 GTE plus 20 IU vitamin $\mathrm{E} / \mathrm{kg}$ diet (treatments 5 and 6 , respectively), showed that higher levels of GTE in the present experiment was more effective than $3 \mathrm{ml} / \mathrm{l} \mathrm{GTE}$ on the antibody response against influenza. Vitamin E alters cytokine production and CD4: CD8 $\mathrm{T}$ cell ration (Erf et al., 1998) and it can activate B cell levels of specific antibodies. Vitamin E supplementation (100 or $250 \mathrm{IU} / \mathrm{kg}$ of diet) was not effective in antibody production of chicks, although it increased the number of macrophages (Qureshi et al., 1993; Marsh et al., 1981). No beneficial effects of 12 or $300 \mathrm{IU} / \mathrm{kg}$ of dietary vitamin $\mathrm{E}$ on mortality rate and pathology induced by E. coli was reported by Sell et al. (1997). The effects of vitamin $\mathrm{E}$ on immune response depends on a variety of factors such as the strain, genetic background (Yang et al., 2000), the amount of vitamin E in the basal diet, level of stress (Mcllroy et al., 1993) and age of the birds, which may explain the discrepancies of reported results. Marsh et al. (1981) and Cook (1991) reported that vitamin E is immunoregulatory only at low antigen levels. It is possible that in this study, the vaccines could have created a higher level of antigen. In the present study, vitamin $\mathrm{E}$ at $20 \mathrm{IU} / \mathrm{kg}$ failed to increase the antibody against Newcastle and Influenza which might be due to the above mentioned factors. It has been reported that dietary levels of $25-50 \mathrm{mg} / \mathrm{kg}$ of vitamin E improved immune while a level of $200 \mathrm{IU} / \mathrm{kg}$ of vitamin $\mathrm{E}$ had a dampening effect on $\mathrm{T}$ helper cell function or cell number (Leshchinsky and Klasing, 2001). Antibody production against $E$. coli and Newcastle disease virus was better when vitamin $\mathrm{E}$ was supplied at 0 to 10 $\mathrm{mg} / \mathrm{kg}$ of feed (Freidman et al., 1998). In the current study, $20 \mathrm{IU} / \mathrm{kg}$ vitamin $\mathrm{E}$ had numerically higher antibody production against SRBC than other treatments. The SRBC is a $\mathrm{T}$ cell dependant antigen, which helps B-cells to produce antibodies (Nelson et al., 1995). T cells help B cells in producing specific antibody through the production of cytokines which promote activation and growth of B cells thus enhance humoral immunity. The assessment of humoral immunity response through the production of hemagglutinin antibodies to SRBC commonly used due to its rapid and does not involve the use of pathogenic agents. Treatment 2 (20 IU vitamin E/kg feed) had higher $(\mathrm{P}<0.05)$ TAC level than other treatments. This was not surprising since vitamin $\mathrm{E}$ is one of the most natural antioxidant and could improve production, strengthen the immunological status and to increase the vitamin $\mathrm{E}$ content of food, thus increase vitamin $\mathrm{E}$ intake of consumer (Sunder et al., 1997; Flachowsky, 2000). Vitamin E supplementation was more effective to improve the serum TAC level of broiler chicks than GTE ( 3 and $5 \mathrm{ml} / \mathrm{l}$ ) or combined with vitamin E. 


\section{Conclusion}

In summary, the results demonstrated that application of $3 \mathrm{ml} / \mathrm{L}$ drinking water GTE had the most positive effects on growth performance and application of $5 \mathrm{ml} / \mathrm{LGTE}$ alone or combination with $20 \mathrm{IU} / \mathrm{kg}$ diet vitamin $\mathrm{E}$ could increase antibody titers of broiler chicks. Dietary vitamin E (20 IU/kg) alone was not effective to enhance the antibody response to some antigens and may have a complementary effect on the serum antibody titers against Influenza and health and may have the potential in replacing antibiotics in broiler chicks. Further research is needed to find the most effective levels of green tea extract and vitamin $\mathrm{E}$ on performance and immunity responses of broiler chicks.

\section{References}

Akhlaghi A, Jafari Ahangari Y, Zhandi M, Peebles ED (2014) Reproductive performance, semen quality, and fatty acid profile of spermatozoa in senescent broiler breeder roosters as enhanced by the longterm feeding of dried apple pomace. Anim Repro Sci 147:64-73.

Biswas AH, Miyazaki Y, Nomura K, Wakita M (2000) Influence of long-term feeding of Japanese green tea powder on lying performance and egg quality in hens. Asian-Aust. J Anim Sci 13: 980-985.

Biswas AH, Wakita M (2001) Effect of dietary Japanese green tea powder supplementation on feed utilization and carcass profile in broilers. $\mathbf{J}$ Poult Sci 38: 50-57.

Blumberg J (1994) Vitamins. In :Diet, Nutrition, and Immunity. Forse R A(ed).CRC Press, Boca Raton, FL. pp: 237-247.

Boren B, Bond P (1996) Vitamin E and immunocompetence. Broiler Industry. November: 26-33.

Brugh M (1978) A simple method for recording and analyzing serological data. Avian Dis 22: 362-365.

Cook ME (1991) Nutrition and the immune response to the domestic fowl. Crit. Rev Poult Biol 3: 167-189.

Erf GF, Bottje WG, Bersi TK, Headrick MD, Fritts CA (1998) Effects of dietary vitamin $\mathrm{E}$ on the immune system in broilers. Altered proportions of CD4 T-cells in the thymus and spleen. Poult Sci 77: 529-537.

Flachowsky G (2000) Vitamin E -transfer from feed into pig tissues. J Appl Anim Res 17: 69-80.

Freidman A, Bartov I, Sklan D (1998) Humoral immune response impairment following excess vitamin $\mathrm{E}$ nutrition in the chick and turkey. Poult Sci 77: 956-962.

Gershwin M, Beach R, Hurley L (1985) The potent impact of nutritional factors on immune response. In: Nutrition and Immunity. Academic Press, New York, NY. pp: 1-7.
Guray E, Nuh O, Aydin A, Soner C (2011) Growth performance, Meat Quality and Caecal Coliform Bacteria Count of Broiler Chicks fed diet with green tea extract. Asian-Aust J Anim Sci 8: 11281135.

Hernandez F, Madrid J, Gracia V, Oregano J, Megias MD (2001) Influence of two plant extracts on broiler performance, digestibility, and digestive organ size. Poult Sci 83: 169-174.

Kaneko K, Yamasaki K, Tagawa Y, Tokunaga M, Tobisa M, Furuse M (2001) Effects of dietary Japanese green tea powder on growth, meat ingredient and lipid accumulation in broilers. $\mathrm{J}$ Poult Sci 38: 77-85.

Kidd MT (2004) Nutritional modulation of immune function in broilers. Poult Sci 63: 650-657.

Klasing KC (1998) Nutritional modulation of resistance to infectious diseases. Poult Sci 77: 1119-1125.

Koo SI, Noh SK (2007) Green tea as inhibitor of the intestinal absorption of lipids. Potential mechanism for its lipid-lowering effect. J Nutr Biochem 18: 179-183.

Kojima S, Yoshida Y (2008) Effects of green tea powder feed supplement on performance of hens in the late stage of laying. Int J Poult Sci 7: 491-496.

Kwon OS, Yoo JS, Min BJ, Son K S, Cho JH, Kim HJ, Chen YJ, Kim IH (2005) Effect Of supplemental medicinal plants (Artemisia, Acanthopanax and Garlic) on growth performance and serum characteristics in lactating sows, suckling and weanling pigs. Kor J Anim and Technol 47: 4: 501512.

Leshchinsky TV, Klasing KC (2001) Relationship between the level of dietary vitamin $\mathrm{E}$ and the immune response of broiler chickens. Poult Sci 80: 1590-1599.

Marsh JA, Dietert RR, Combs GF (1981) Influence of dietary selenium and vitamin $\mathrm{E}$ on the humoral immune response of chicks. Pro Soc Exp Biol Med 166:228-238.

McDowell LR (1989) Vitamins in animal nutrition. In: McDowell, L R (Ed.), Comparative Aspects to Human Nutrition. Vitamin E .Academic Press, London, pp: 93-131.

Mcllroy SG, Goodall E, Rice D, McNultry M, Kennedy DG (1993) Improved performance in commercial broiler flocks with subclinical infectious bursal disease when fed diets containing increased concentrations of vitamin E. Avian Pathol 22: 8194.

Miller NJ , Rice-Evans C, Davies M J, Gopinathan V, Miller A (1993) A novel method for measuring antioxidant capacity and its application in monitoring the antioxidant status in premature neonates. Clin Sci (London) 84: 407-412. 
Nelson N A, Lakshmanan N, Lamont S J (1995) Sheep red blood cell and Brucella abortus antibody responses in chickens selected for multititrat immunocompetence. Poult Sci 74: 1603-1609.

Panja P (2005) The effects of china tea (Camellia Sinensis) supplementation in laying hen diets on production, quality and cholesterol content of egg. 15th Eur. Symp. in Poult Nutr pp: 609-611.

Papuc C, Diaconescu C, Nicorescu V, Crivneanuc C (2007) Antioxidant properties of aromatic plants alcoholic extracts. Roum. Biotechnol. Lett 12: 3533-3537.

Papuc C, Diaconescu C, Nicorescu V, Crivneanuc C (2008) Antioxidant activity of sea buckthom (Hipppphae rhmnoides) alcoholic extract. Rev Chem 59: 392-394.

Phillips I, Casewel M, Cox T, Groot B, Friis C, Jones R, Nightingle C, Preston R, Waddell J (2004) Does the use of antibiotics in food animals pose a risk to human health? A critical review of published data. J Antimic Chemothe 53:25-52.

Qureshi M A, Ferket P R, Garlich J D (1993) Effects of dietary supplementation of vitamin $\mathrm{E}$ on the immune function of turkey poults. Poult Sci 72(Suppl.1) 56 (Abstr.).

Radcliff M M (2000) Dying inside the walls. J Palliat Med 3: 509-511.

Ramadan M F, Kroch L W, Moers J T (2003) Radical scavenging activity of black cumin (Nigella sativa), coriander (Coriandrum sativum) and Niger (Guizotia abyssinica) crude seed and oil fractions Agric Food Chem 51: 6961-6969.

SAS (1996) Statistical Analysis System. SAS Inst., Cary, NC, USA.

Sarker M, Kim G, Yang C (2010) Effect of green tea and biotite on performance, meat quality and organ development in Ross broiler. J Egypt Poult Sci 30: 77-88.

Sell JL, Trampel DW, Griffith RW (1997) Adverse effects of Escherichia coli infection of turkey were not alleviated by supplemental dietary vitamin E. Poult Sci 76: 1682-1687.

Singh H, Sodhi DS, Kaur R (2006) Effect of dietary supplements of selenium, vitamin $\mathrm{E}$ or combination of the two on antibody response of broiler. $\mathrm{Br}$. Poultry Sci 47: 714-719.

Sunder A, Richard G, Flachowsky G (1997) Influence of different concentrations of vitamin $\mathrm{E}$ in the feed of laying hens on the vitamin E -transfer into egg. Pro Soc Nut Physiol 6: 14-152.

Tengerdy RP, Nockels CF (1975) Vitamin E or vitamin A protects chickens against E.coli infection. Poult Sci 54: 1292-1296.

Uuganbayar D (2004) A study on the utilization of green tea for laying hens and broiler chicks.A Dissertation for the degree of doctor of philosophy. Sunchon National University.Sunchon, Korea.

Uuganbayar D, Bae IH, Cho KS, Shin IS, Firman JD, Yang CJ (2005) Effects of green tea powder on lying performance and egg quality in laying hens. Asian-Aust J Anim Sci 18: 1769-1774.

Valko M, Leibfritz D, Moncol J, Cronin MTD, Mazur M, Telser J (2007) Free radicals and antioxidants in normal physiological functions and human disease. Int J Biochem Cell Biol 39:44-84.

Williams P, Losa R (2001) The use of essential oil and their compounds in poultry nutrition. World Poult 17:14-15.

Yang N, Larsen CT, Dunnington EA, Geraert PA, Picard M, Siegel PB (2000) Immune competence of chicks from two lines divergently selected for antibody response to sheep red blood cells as affected by supplemental vitamin E. Poult Sci 79: 799-803.

Yang CJ, Yang IY, Oh DH, Bae IH, Cho SG, Kong IG, Uuganbayar D, Choi KS (2003) Effect of green tea by-product on performance and body composition in broiler chicks. Asian-Aust J Anim Sci 16: 867872 . 